\title{
Relating Company Size and Financial Performance in Agricultural Firms Listed in the Nairobi Securities Exchange in Kenya
}

\author{
Samuel Kanga Odalo ${ }^{1}$, George Achoki ${ }^{1} \&$ Amos Njuguna ${ }^{1}$ \\ ${ }^{1}$ Chandaria School of Business, United States International University Africa, Nairobi, Kenya \\ Correspondence: Samuel Kanga Odalo, Chandaria School of Business, United States International University \\ Africa, P. O. Box 4920-00100, Nairobi, Kenya. Tel: 254-711-474-215. E-mail: samuelodalo@ gmail.com
}

Received: June 25, 2016

Accepted: July 13, 2016

Online Published: August 25, 2016

doi:10.5539/ijef.v8n9p34

URL: http://dx.doi.org/10.5539/ijef.v8n9p34

\begin{abstract}
Company/firm size is among the many variables that is significant in assessing the profitability of a company. Therefore, this paper seeks to evaluate the effect of company size on the financial performance of listed agricultural companies in Kenya. The theory of economies of scale that links benefits arising from company size, cost management and production volumes was utilized. Secondary data was extracted from the annual reports comprising of financial statement from the period 2003 to 2013 and analyzed using a pooled OLS model. Company size was measured using the total assets ( $\log$ of assets) while financial performance was measured by return on assets (ROA), return on equity (ROE) and earnings per share (EPS). The regression results present the goodness of fit for the regression between log total asset and ROA, ROE and EPS as 0.112, 0.113 and 0.074 respectively. The overall model of ROA, ROE and EPS was significant with F statistic of 9.334, 11.096 and 5.901 respectively. The relationship between log total asset and financial performance measures was positive and significant for ROA $(b 1=0.033, p$ value, 0.003$)$ and ROE $(b 1=0.049, p$ value, 0.001$)$ and. EPS $(b 1=3.866, p$ value, 0.018 ). These results indicate that company size as measured by total assets affects financial performance of agricultural companies listed in NSE positively and significantly. Company size had positive and statistical significance on all the three indicators of the financial performance disclosing that large companies were found to have a competitive advantage over small firms.
\end{abstract}

Keywords: company size, financial performance, agricultural firms, Nairobi securities exchange, return on assets, return on equity, earnings per share

\section{Introduction}

\subsection{Background}

According to Wang (2008), stake holders are usually interested in the financial performance of companies associated with them. These stakeholders are not limited to shareholders only but include suppliers, employees and the government.

Firms are mostly concerned with their profitability, as profitability serves as one of the objectives of business necessary for longtime survival.

The commonly used measures to gauge financial performance in companies include return on assets (ROA), return on equity (ROE) and net margin on sales. Financial performance measures serve as a basis for evaluating the performance of a corporate entity (Liebrand, 2007). Gao (2010) observed that agriculture is the foundation of the national economy in India. He explains that India is a large agricultural country where listed agricultural firms are faced with worsening financial performances despite being financed from the capital market.

Financial performance problems are also experienced in China with declining performances being experienced. These have affected the competiveness of listed agricultural firms in the country necessitating a better understanding of the factors into play for the improvement of their financial performance (Peng, 2006). In support, Hao (2011) stated that due to the large population of China, and a small per capita field area, the improvement of the productivity of the agricultural sector is vital for the economy.

Qin, Fu, Ma, and Li (2011) showed that listed agricultural firms are essential for the sustainable development of agriculture. The small population quantity, slow development, weak growing capacity, relatively poor rationality and unbalanced regional distribution situation of China's agricultural listed firms have seriously restricted the 
development of China's agricultural economy. In Africa, Agriculture contributed to the Malawi's economy leading to self sufficiency in food after gaining self rule due to the involvement of the government (Harrigan, 1991). In Kenya, listed companies operate in the most important sector of the country's economy. This is necessary for the stability and wellbeing of the country and its people. These sectors represent diversified businesses that include; agricultural, automobiles and accessories, commercial, construction and allied, energy and petroleum, insurance, investments, manufacturing and allied industries, telecommunication and technology, and growth and enterprise market segment (NSE, 2014). Accordingly, by the growing empirical evidence of a positive finance-growth nexus, capital market development has remained Kenya's strategic development goal since the mid-1980s (Jayne, Govereh, Mwanaumo, Nyoro, \& Chapoto, 2015). As stated by Omboi (2011), Kenya is largely dependent on the agricultural sector. The sector contributes to the economy directly as well as supports other sectors by providing the inputs, food and employment.

\subsection{Problem Statement}

According to the NSE (2014) report, the shares in the agriculture listed companies were lagging behind other listed companies in the market from the investor's point of view. This was attributed to the low returns from the sector. This view is supported by The Kenya Economic Report, 2013 which indicated that the performance of the agricultural sector in Kenya had been affected by unfavorable weather patterns that significantly reduced the tea, coffee and horticulture production. This decline in production continued in subsequent years and affected the overall, agricultural production in Kenya as well as country's economy's growth as confirmed by the Government of Kenya (2014).

Despite the support from the government, the agricultural sector in Kenya has continued to perform poorly leading to the closure of some of the companies. The Government has continued to intensify efforts to identify the other controllable factors affecting the agriculture performance in the country (PDA, 2010; KDB, 2010).

\subsection{Emperical Review}

Locally, several studies including Omondi and Muturi (2013) investigated the factors affecting the financial performance of listed companies at the Nairobi securities exchange in Kenya and concluded that leverage had a significant negative influence on financial performance while liquidity, company size and age of firm had a significant positive influence on financial performance.

Omboi, (2011) focused on the reasons for low listing of agricultural companies and noted that no agricultural company has featured in the aforementioned IPOs leave alone seeking additional funds through the bourse. One of the reasons for this is the lack of confidence in the NSE and inadequate public awareness. However, the increasing list of initial public offers (IPO) and right issues in recent times is a testimony of the increased awareness and recognition of the stock market as a place to raise capital. Maina and Sakwa (2010) selected firms in five sectors of the Nairobi Stock Exchange and sought to understand the financial distress of listed companies. They analyzed the financial statements and noted that the financial health of listed companies needed to be improved and that there is a missing link between surveillance and the management of these firms. If this is not rectified the public could lose interest in investing in Nairobi Stock Exchange.

Further, most of the local studies highlighted used simple regression while this study adopted panel data methodology. Omondi and Muturi (2013) which is closer to this study utilized data running from the year 2006 to 2012 while the current study utilized data from the year 2003 to 2013. In addition, while Omondi and Muturi (2013) used only a single measure of the financial performance (ROA) the current study is using three measures of financial performance (ROA, ROE and EPS). The study focused on the effect of company size on the financial performance of agricultural firms listed at the Nairobi Securities Exchange.

The study will be useful to various stakeholders including: policy makers and analysts, investors, executives and managers, employees, creditors, government and regulatory authorities, shareholders, competitors, financial reporters, and scholars. Therefore, based on the research objective, the dependent variable is financial performance (ROA, ROE, EPS) while the independent variable is represented by the company size as measured by total assets represented by the natural $\log$ of total assets.

According to Bhunia and Khan (2011), there are different approaches of measuring Company/firm size which includes natural $\log$ of assets, sales, number of employees and log of market capitalization. This study employed natural $\log$ of total assets as a measure of company size. This measure is the most popular firm size proxy in empirical corporate finance research. Several studies including Pervan and Višić, (2012); Vijayakumar and Tamizhselvan (2010); Linck, Netter, and Yang (2008); Lemmon, Roberts, and Zender (2008); Graham, Li, and Qiu (2012) have utilized log of total assets as a measure of company size. Larger firms are associated with having more 
diversification capabilities, ability to maximize on economies of scale and also being highly formalized in terms of procedures. These features discussed are all geared towards making the operations influence so as to enable the firm generate superior performance (Bhunia \& Khan, 2011). However others like, Choi (2008) argues that firm size can lead to inferior performance due to formalized procedures and market $\mathrm{x}$-inefficiencies. Larger firms can also attract exemplary human resources that will significantly contribute to the firm performance. Pervan and Višić (2012) conducted a study on firm size and business success. The analysis was conducted for the 2002-2010 period using natural logarithms as a measure of firm size. The results established that firm size has a significant positive (although weak) influence on firm profitability.

A positive relationship between firm size and profitability was found by Vijayakumar and Tamizhselvan (2010). In their study, which was based on a simple semi- logarithmic specification of the model, the authors used different measures of size (sales and total assets) and profitability (profit margin and profit on total assets) while applying model on a sample of 15 companies operating in South India. Choi (2008) found that in Korea, firm size has a significant positive influence on its financial performance. He attributed this to availability of financial resources, manpower and innovation.

Papadogonas (2007) analyzed manufacturing firms in Greek and concluded that large firms were more profitable but less productive. This is consistent with Pervan and Visic (2012), in a study in Croatia, claim that the influence of firm size and profitability is affected by the neoclassical view of the firm and the concept of economies of scale.

Vishal and Saravanan (2007) explore the influences of firm size on turnover in U.S and found a diminishing relationship between returns and size. Lee (2009) as cited by Pervan and Visic (2012) examines the relationship between firm size and profitability. Using panel data, the results indicated a non linear relationship in large firms where, profits are lower. Amato and Burson (2007) found a linear relationship between firm size and profitability. A negative insignificant relationship between firm size and profitability was evident.

Uke and Suhadak (2014) seek to unravel the key variables that genuinely influence company profitability and the Firm Value. Clustering the companies by their asset sizes i.e. Large and Small Groups, marks the novelty of this research. They used a Generalized Structured Component Analysis (GSCA) to measure the effect of Company Size and Capital Structure towards Liquidity, Financial Performance and Firm Value and to prove the moderation between the two company size clusters. This research concluded that there is essentially a significant different characteristic between the two groups, regarding the influence of the endogenic variables towards exogenic variable. They further concluded that the influence of endogenic variables towards exogenic variables is not an identical one to another, when there is different asset size involved.

\subsection{Theoretical Review}

This study is anchored on the theory of economies of scale. The theory of Economies of Scale was laid out by Marshall (1890) in his attempt to explain increasing returns and competition. (Hitt \& Ireland, 1987). Marshall's effort was to explain the association between reduced costs and increases in outputs. He considered the effects of both the external and internal economies to the small firms (Pervan \& Visic, 2012; Saleem \& Rehman, 2011; Roy $\&$ Wilfred, 2011).

Therefore, economies of scale refer to internal, external, national, international, aggregative or dis-aggregative and to the advantages due to size and scale of operation of firms (Hitt \& Ireland, 1987).

Firm size has been associated with performance of large firms due to various reasons including market power, research, aggregation of production processes and research and development efforts. Large firms are therefore able to spread costs over the large production realized (Stefanou, 2006; Gomes, Kruglianskas, \& Scherer, 2009; Gay, 1981; Colburn \& Talley, 1992; Panzar \& Willig, 1981; Cohen, 1995; Colburn \& Talley, 1992; Ross, 2000; Sah \& Stiglitz, 1988; Panzar \& Willig, 1981)

Therefore, the economies of scale theory explain the cost advantages that enterprises obtain due to size, output or scale of operation.

\section{Method}

The research design was descriptive and causal focused to bring out the correlation of variables and establish how one variable affects changes in another consistent with Saunders, Lewis, and Thornhill (2012). Panel data for the 7 listed agricultural companies for the period 2003 to 2013 was utilized. The secondary data was obtained from the audited financial statements available from the Companies and records of the regulatory authorities (CMA and NSE). Data was extracted for the financial performance (ROA, ROE, and EPS) and company size (total assets). Diagnostic tests were conducted to confirm the assumptions of the OLS. A pooled OLS regression model was used to estimate the relationship between the company size and financial performance using the following model in 
STATA 11.0 software;

$$
Y=\beta_{0}+\beta_{1} X+\mu
$$

Where;

$\mathrm{Y}=$ Financial performance as proxied by return on assets (ROA), return on assets (ROE) and earnings per share (EPS).

$\mathrm{X}=$ Company Size (Log of total assets)

The specific models are as follows;

ROA $=\beta_{0}+\beta_{1}$ Company Size $+\mu$

$\mathrm{ROE}=\beta_{0}+\beta_{1}$ Company Size $+\mu$

EPS $=\beta_{0}+\beta_{1}$ Company Size $+\mu$

In the model, $\beta_{0}=$ the constant term. While the coefficient $\beta_{\mathrm{i}} \mathrm{i}=1$ measures sensitivity of Financial performance to unit change in Company size to; $\mu=$ error term

The model significance test using ANOVA and coefficient of determination calculated. Other tests including pre-estimation tests for multicollinearity and Hausman were conducted. Significance was determined using critical $\mathrm{p}$ value of 0.05 .

\section{Results}

\subsection{Descriptive Statistics}

The total mean of $\log$ total asset for the period 2003 to 2013 was 13.915 with a standard deviation of 1.54 indicating small variability in log total asset over time. The minimum and maximum values of log total assets over the same period of time were 10.77 and 16.07 respectively as indicated in Table 1.

Table 1. Descriptive statistics

\begin{tabular}{lccccccc}
\hline Variable & years & Observations & Mean & Std Deviation & Std. Error & Min & Max \\
\hline Log of total assets & $\mathbf{2 0 0 3 - 2 0 1 3}$ & $\mathbf{7 2}$ & $\mathbf{1 3 . 9 1 5 9}$ & $\mathbf{1 . 5 3 5 6 2}$ & $\mathbf{. 1 8 0 9 7}$ & $\mathbf{1 0 . 7 7}$ & $\mathbf{1 6 . 0 6}$ \\
\hline
\end{tabular}

\subsection{Trend Analysis}

Figure 1 shows the total asset trend as proxy by the log of the total assets for the seven companies from the year 2003 to 2013. The trend line indicates that the log total trend has been increasing. Log total assets declined from the year 2003 to 2006 but rose again from year 2007 to 2012 before declining in the year 2013.

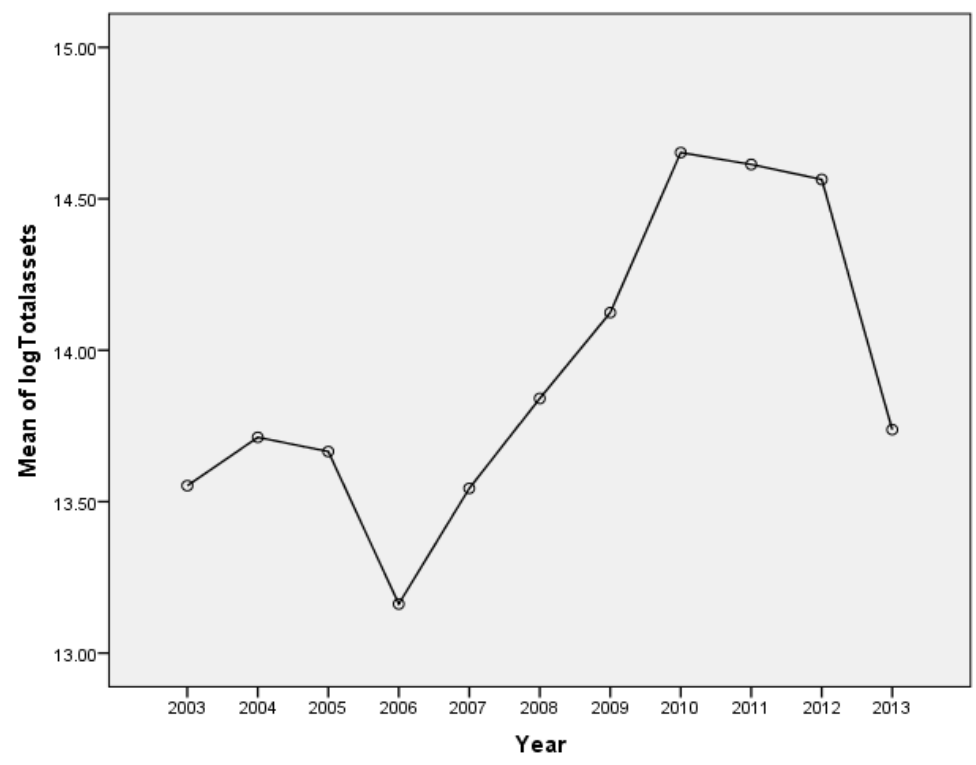

Figure 1. Total asset trend 


\subsection{Correlation Analysis}

Total asset is positively and significantly related with ROA $(\mathrm{r}=0.335, \mathrm{p}=0.003)$, positively and significantly related to $\operatorname{ROE}(\mathrm{r}=0.361, \mathrm{p}=0.001)$ and positively and significantly related to EPS $(\mathrm{r}=0.272 \mathrm{p}=0.018)$ as indicated in Table 2.

Table 2. Correlation analysis results

\begin{tabular}{|c|c|c|c|c|c|}
\hline & & ROA & ROE & EPS & Log Total Assets \\
\hline \multirow[t]{2}{*}{ ROA } & Pearson Correlation & 1.000 & & & \\
\hline & Sig. (2-tailed) & & & & \\
\hline \multirow[t]{2}{*}{ ROE } & Pearson Correlation & $.992 * *$ & 1.000 & & \\
\hline & Sig. (2-tailed) & 0.000 & & & \\
\hline \multirow[t]{2}{*}{ EPS } & Pearson Correlation & $.253^{*}$ & $.263^{*}$ & 1.000 & \\
\hline & Sig. (2-tailed) & 0.027 & 0.022 & & \\
\hline \multirow[t]{2}{*}{ Log Total Assets } & Pearson Correlation & $.335 * *$ & $.361 * *$ & $.272 *$ & 1.000 \\
\hline & Sig. (2-tailed) & 0.003 & 0.001 & 0.018 & \\
\hline
\end{tabular}

Note. ${ }^{* *}$ Correlation is significant at the 0.01 level (2-tailed).

* Correlation is significant at the 0.05 level (2-tailed).

\subsection{Regression Analysis}

Regression analysis was conducted to empirically determine whether Company size (log total asset) was a significant determinant of performance which is measured in ROA, ROE and EPS. The regression results presented in table 3, presents the goodness of fit for the regression between log total asset and ROA as 0.112. An R squared of 0.112 indicates that 11.2 per cent of the variations in ROA are explained by log total asset. While 13 per cent of ROE is explained by log total asset and 7.4 per cent of EPS is explained by log total asset.

The overall model significance is also presented in Table 3. The overall model of ROA was significant with $\mathrm{F}$ statistic of 9.334. The overall model of ROE was significant with F statistic of 11.096 while for EPS was significant with $\mathrm{F}$ statistic of 5.901. The relationship between log total asset and ROA is positive and significant $\left(b_{1}=0.033, p\right.$ value, 0.003). Log total asset and ROE is positive and significant $\left(b_{1}=0.049, p\right.$ value, 0.001$) . \log$ total asset and EPS is positive and significant $\left(b_{1}=3.866\right.$, $p$ value, 0.018$)$.

Table 3. Regression analysis for company size (log total assets) and financial performance (ROA, ROE, and EPS)

\begin{tabular}{lccc}
\hline & ROA & ROE & EPS \\
\hline Parameter estimate & Coefficient $(\mathrm{P}$ value $)$ & Coefficient(P value $)$ & Coefficient(P value \\
\hline Constant & $-0.102(0.145)$ & $-0.152(0.111)$ & $-14.579(0.158)$ \\
Log total assets & $0.033(0.003)$ & $0.049(0.001)$ & $3.866(0.018)$ \\
R Squared & 0.112 & 0.130 & 0.074 \\
F statistic (ANOVA) & $9.334(0.003)$ & $11.096(0.001)$ & $5.901(0.018)$ \\
\hline
\end{tabular}

The regression equation is as follows;

$$
\begin{aligned}
& R O A=-0.102+0.033 \text { Logtotal asset } \\
& R O E=-0.152+0.049 \text { Logtotal asset } \\
& E P S=-14.579+3.866 \text { Logtotal asset }
\end{aligned}
$$

\section{Discussion}

The study sought to establish the effect of company size on the financial performance of the seven listed agricultural companies in the NSE. The results showed that company size had a positive effect on return on assets (ROA). The analysis produced a coefficient of determination which showed the percentage of variations in ROA which is explained by company size. The significance test showed that influence of company size on ROA was statistically significant and hence the alternate hypothesis was accepted. The study also revealed that company size had a positive and significant relationship with ROE and EPS. The findings of this study agree with those of Omondi and Muturi (2013) who investigated the factors affecting the financial performance of listed companies at 
the NSE. The study concluded that company size had a significant positive influence on financial performance. The large companies were found to have a competitive advantage over small firms as large firms had a wide array of resources and also enjoyed economies of scale, hence were in a better position to compete in the market. However, for firms that become extremely large, the influence of size could be negative due to bureaucracy and other reasons. Pervan and Visic (2012) also posit that the influence of firm size and profitability is affected by the neoclassical view of the firm and the concept of economies of scale.

These finding agrees with Damanpour, Walker, and Avellaneda (2009) who evaluated the influence of the size of the company in the practices of management of external sources of technological information and the correspondent impacts of these practices in the innovation performance of the enterprise. This was consistent with Vijayakumar and Tamizhselvan (2010); Papadogonas (2007); Bhutta and Hasan (2013) who found a positive relationship between firm size and profitability. Lee (2009) while examining the role that firm size played in profitability found out that the firm size played an important role in explaining profitability. However, some significant differences between small and larger firms on how these managerial practices affect the innovative performance were detected by Uke and Suhadak (2014) and Mang'eli (2012).

\section{References}

Amato, L. H., \& Burson, T. E. (2007). The effects of firm size on profit rates in the financial services. J. Econs. Econ. Edu. Res., 8(1), 67-81.

Bhunia, A., \& Khan, I. U. (2011). Liquidity Management Efficiency of Indian Steal Companies: A Case Study. Far East Journal of Psychology and Business, 3(3), 3-13.

Choi, W. (2008). Korea's FTA Progress and Its Implications. Negotiation and Korea, 1(1), 40-41. Seoul: Korean Association of Negotiation Studies.

Cohen, W. M. (1995). Absorptive capacity: A new perspective on learning and innovation. Administrative Science Quarterly, 35(1), 128-152. http://dx.doi.org/10.2307/2393553

Colburn, C., \& Talley, W. (1992). A Firm-Specific Analysis of Economies of Size in the U.S. Urban Multiservice $\begin{array}{llll}\text { Transit Industry. } & \text { Transportation }\end{array}$ http://dx.doi.org/10.1016/0191-2615(92)90024-Q

Damanpour, F., Walker, R. M., \& Avellaneda, C. N. (2009). Combinative influences of innovation types and organizational performance: A longitudinal study of service organizations. Journal of Management Studies, 46(4), 650-675. http://dx.doi.org/10.1111/j.1467-6486.2008.00814.x

Gao, Y. (2010). Study on Formative Mechanism of Financial Risk and Control for Agriculture Listed Companies in China. College of Economy and Management, Southwest University, Beibei, Chongqing, China.

Gay, L. R. (1981). Educational Research: Competencies for Analysis and Application. Charles E. Mairill Publishing Company, A Bell and Howell Company, Columbus, Toronto; London. Cited in Mugenda, O. M., \& A. G. Mugenda (2003). Research Methods: Quantitative and Qualitative Approaches. Nairobi, KE: Afr. Centre Technol.

Gomes, C. M., Kruglianskas, I., \& Scherer, F. L. (2009). Company Size Effect in Innovative Performance. Journal of Technology Management \& Innovation, 4(4), 61-81.

Government of Kenya. (2014). Economic Survey. Nairobi, KE: Kenya National Bureau of Statistics.

Hao, X. (2011). An Analysis of Firms Performance Evaluation of Agricultural Listed Firms Based on Factor Analysis. Economic Research Guide, 35, 124-125.

Harrigan, W. L. (1991). Diversified Growth and Competition: The experience of twelve large UK firms. Applied Economics, 17(10), 827-847.

Hitt, M. A., \& Ireland, R. D. (1987). Peters and Waterman revisited: The un-ended quest for excellence. Academy of Management Executives, 1(2), 91-98. http://dx.doi.org/10.5465/AME.1987.4275812

Jayne, T. S., Govereh, J., Mwanaumo, A., Nyoro, J. K., \& Chapoto, A. (2002). False Promise or False Premise? The Experience of Food and Input Market Reforms in Eastern and Southern Africa. World Development, 30(11), 1967-1985. http://dx.doi.org/10.1016/S0305-750X(02)00115-8

Kenya Dairy Board. (2010). Annual report for Kenya Dairy Board Coast region. Kenya.

Kenya Economic Report. (2013). Creating an Enabling Environment for Stimulating Investment for Competitive and Sustainable Counties. Nairobi, KE: Kenya Institute for Public Policy Research and Analysis (KIPPRA). 
Liebrand, R. I. (2007). Statistics for Management (7th ed.). Prentice Hall.

Maina, F. G., \& Sakwa, M. M. (2010). Understanding Financial distress among listed firms in Nairobi stock exchange: A quantitative approach using the z-score Multi-Discriminant Financial analysis model. Nairobi, KE: Jomo Kenyatta University of Agriculture and Technology.

Mang'eli, M. Y. (2012). Relationship between interest rate spread and financial performance of the commercial banks in Kenya. Doctoral dissertation, school of business, University of Nairobi, KE: University of Nairobi.

Marshall, A. (1890). Principles of Economics. London, UK: Macmillan.

Nairobi Securities Exchange. (2014). Retrieved February 28, 2014 from http://www.nse.co.ke/

Omboi, B. M. (2011). Reasons for Low Listing by Agricultural Companies in the Bourse: A Case Study of DelMonte Limited Kenya. Research Journal of Finance and Accounting, 2(3), 57-60.

Omondi, M. M., \& Muturi, W. (2013). Factors Affecting the Financial Performance of Listed Companies at the Nairobi Securities Exchange in Kenya. Research Journal of Finance and Accounting, 4(15).

Panzar, R., \& Willig, M. (1981). Estimating Cost Functions for Rail Rapid Transit Properties. Transportation Research, 12(2), 73-78.

Papadogonas, T. A. (2007). The financial performance of large and small firms: Evidence from Greece. Inter. J. Finan. Serv. Manage., 2(1/2), 14-20. http://dx.doi.org/10.1504/ijfsm.2007.011668

PDA. (2010). Guidelines on Corporate Governance in public listed Companies in Kenya. Kenya Gazette Notice No. 369, pp. 122-128. Companies Act Chapter 486, Laws of Kenya.

Peng, Y. (2006). Study on the Operating Performance of the Agricultural Listed Companies in China - Based on the Background of Transformation Economic. Zhengjiang University.

Pervan, M., \& Višić, J. (2012). Influence of firm size on its business success. Croatian Operational Research Review, 3(1), 213-223.

Qin, Z. G., Fu, L. M., Ma, C., \& Li, D. S. (2011). Comparative Analysis of the Development of Agricultural Listed Companies. Journal of Anhui Agricultural Science, 39(10), 62-64.

Ross, S. A. (2000). The Economic Theory of Agency: The Principal's Problem. The American Economic Review.

Roy, J. R., \& Wilfred, J. E. (2011). Protectionism and Increasing Returns with Comparative Cost Disadvantage. PIER Working Paper, 011-027.

Sah \& Stiglitz. (1988). Containership Market Report. Journal of Commerce, 20, 1999-2003.

Saleem, Q., \& Rehman, R. U. (2011). Impacts of liquidity ratios on profitability: Case of oil and gas companies of Pakistan. Interdisciplinary Journal of Research in Business, 1(7), 95-98.

Saunders, M., Lewis, P., \& Thornhill, A. (2012). Research methods for business students (6th ed.). Pearson professional Limited.

Stefanou, C. (2006). The Complexity and the Research Area of AIS. Journal of Enterprise Information Management, 19(1), 9-12. http://dx.doi.org/10.1108/17410390610636841

Uke, M. S., \& Suhadak, S. R. H. (2014). The Influence of Company Size and Capital Structure towards Liquidity, Corporate Performance and Firm Value, for Large and Small Group Companies. European Journal of Business and Management, 6(18), 2222-2839.

Vijayakumar, A., \& Tamizhselvan, P. (2010). Corporate size and profitability: An empirical analysis. College Sadhana - Journal for Bloomers of Research, 3(1), 44-53.

Vishal, G., \& Saravanan, K. (2007). The Effect of Firm Size and Sales Growth Rate on Inventory Turnover Performance in the U.S. Retail Sector. Journal of Management and Enterprises Development, 8(2), 68-78.

\section{Copyrights}

Copyright for this article is retained by the author(s), with first publication rights granted to the journal.

This is an open-access article distributed under the terms and conditions of the Creative Commons Attribution license (http://creativecommons.org/licenses/by/4.0/). 